\title{
Corporate Payouts, Macroeconomic Influences and Industry Effects
}

\author{
Lauren LoRe ${ }^{1} \&$ Mahfuz Raihan ${ }^{2}$ \\ ${ }^{1}$ Gore School of Business, Westminster College, Salt Lake City, Utah, USA. \\ ${ }^{2}$ University of Utah, Salt Lake City, Utah, USA. \\ Correspondence: Lauren LoRe, Gore School of Business, Westminster College, 1840 South 1300 East, Salt Lake City, \\ Utah, USA.
}

Received: June 1, 2016

doi:10.11114/afa.v2i2.1653
Accepted: June 15, $2016 \quad$ Available online: July 14, 2016

URL: http://dx.doi.org/10.11114/afa.v2i2.1653

\begin{abstract}
The objective of this study is to examine the dynamic nature of dividends and repurchases by examining the effect of industry group and macroeconomic factors on aggregate payout activity between 1985 and 2011. The article applies new tools that include a random-effect, a fixed-effect, and a Generalized Method of Moments (GMM) model. The results highlight new perspectives and support the need to interpret corporate payout determinants within the context of macroeconomic factors and industry group effects.
\end{abstract}

Keywords: corporate payouts, dividends, stock repurchases, industry effects, macroeconomic influences

\section{Introduction}

Corporate payouts, both dividends and stock repurchases, are the result of a management decision to compensate investors. Payouts fluctuate dramatically and are a heavily researched area of corporate finance. In spite of decades of work, there is not one, comprehensive theory that explains why firms initiate pay- outs. The literature in this area focuses on using firm level characteristics to explain why firms pay and how much they pay. Decades of work continue to support the importance of earnings and the influence of previous payout activity ( Lintner, 1956, Brav, Graham, Harvey and Michaely, 2005); however unexplained activity and variation remain. Motivated by asset pricing theory, which has long recognized that investors are exposed to business cycle uncertainty and macroeconomic risk (Yule, 1927; Frisch, 1933), I apply new methods to explore non-firm level influences on aggregate payout activity. These are not new questions, but new methods do allow for a more comprehensive analysis of complex interactions. Hansen (2014) considers the uncertainty inside and outside of economic models and refers to "endogenous transmission mechanisms" where macroeconomics connects with finance. Corporate payouts provide a venue to engage with this issue and examine connections between macroeconomics and finance.

For decades, corporate payouts have fluctuated significantly and Floyd, Li and Skinner (2015) provide a comprehensive overview of the variability in payout activity. They examine activity from 1980 to 2011 and from their data a number of different stories emerge. The 1980's brought a regulatory change that set the stage for the 1990's to be about the growth in repurchases. Repurchases for US industrial firms grew over 275\%, from \$46 billion in 1990 to \$173 billion in 1999. During this same time, dividends grew $14 \%$ from $\$ 123$ billion to $\$ 141$ billion. The following decade must be examined within the context of pre and post financial crisis. From 2001 to 2007, the story was about increasing payouts and reaching new levels for both repurchases and dividends. In 2007, prior to the financial crisis, dividends reached \$216 billion and repurchases $\$ 448$ billion. The story following the financial crisis is one of resilient dividends and an incomplete recovery in repurchases. Dividends dropped $4 \%$ in 2009, and had not only recovered, but reached a new high in 2011 of $\$ 230$ billion. Repurchases were, as expected, more volatile and dropped 58\% in 2009. Repurchases were at $75 \%$ of the 2007 levels in 2011.

Based on the existing theoretical framework, we expect earnings to show a close relation to these volatile changes, but that is not the case. Again referring to Floyd, Li and Skinner (2015), from 1990 to 1999, US industrial earnings grew $84 \%$. This is in stark contrast to a 380\% increase in repurchases. From 2000 to 2007, earnings grew 15\%, while dividends grew 56\% and repurchases grew 223\%. During the financial crisis, earnings dropped $40 \%$, while dividends only declined $5 \%$ and repurchases dropped dramatically by $71 \%$. Figure 1 is based on my data and reflects trends similar to those described in the literature. 
In this paper, I examine the dynamic nature of aggregate payout activity by looking beyond firm-level, cross-sectional determinants. Allen and Michaely (2002) suggest that corporate payouts are not so much the result of a set equation, but are the result of a series of corporate decisions that are both dynamic and consistent. They suggest that these decisions are impacted by determinants that fluctuate over time, resulting in changes in payout activity. I follow this work and focus on examining unexplained variation in aggregate dividend and aggregate repurchase activity by considering factors that may influence and cause changes in the determinants of payout activity. This study focuses on analyzing the influence of an industry group effect and macroeconomic factors on aggregate payout activity. The purpose of this paper is to see if these factors are significant influences and contribute to explaining, what is currently unexplained variationin payout activity.

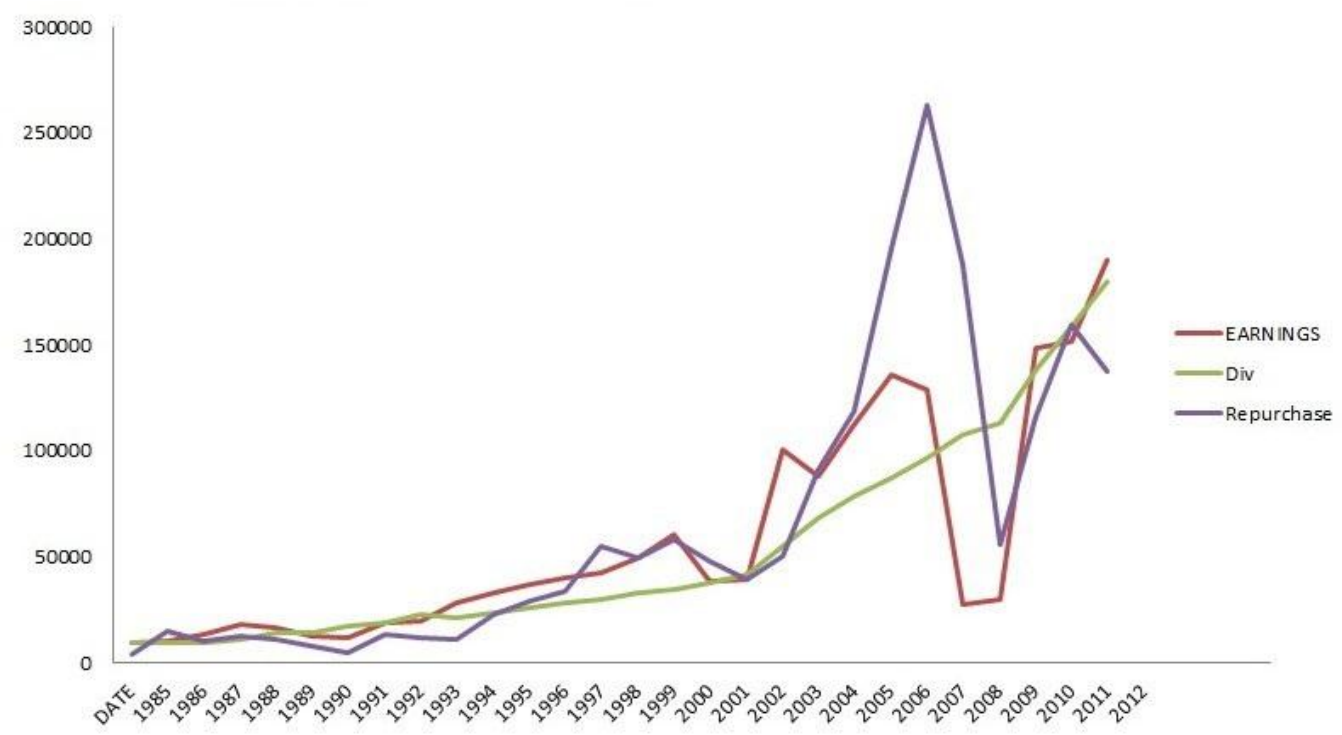

Figure 1. All US firms, 1985-2012: Total earnings, total dividends and total repurchases (expressed in 2011 dollars)

This research extends the literature in three areas: corporate payouts, corporate event waves and capital structure and macroeconomic links. Corporate payout research has emphasized understanding why firms pay, how much they pay and what form the payout takes. Answers to these question rely heavily on the supply side of the equation, with an emphasis on firm level characteristics and earnings. At the firm level, the goal is to generate, and ultimately distribute excess free cash flow to shareholders. In addition to earnings, investment opportunities are also key. It is generally agreed that as investment increases, payouts decrease, and when investment declines, more funds are available for shareholders. The life cycle theory of payouts (Grullon et al., 2002; DeAngelo and DeAngelo, 2006) goes further and considers tradeoffs between the costs and benefits of payout and retention. The life cycle theory considers the time-varying costs and benefits of payouts and retention as the foundation of a more comprehensive explanation of payout behavior. The focus remains on the need to deliver free cash flow to shareholders, but additional issues are taken into account. This theory considers the managerial incentives for payout along with the capital requirements for investment to be the basis for an optimal payout policy.

The area of corporate event waves looks beyond firm level characteristics to explain waves and patterns in self-selected corporate events. The findings in these areas support two theoretical approaches to payout activity: the market driven hypothesis and the neoclassical efficiency hypothesis (Baker, Stein and Wurgler, 2003; Dittmar and Dittmar, 2008; DeAngelo, DeAngelo and Stulz, 2010). The market driven hypothesis suggests corporate actions are initiated to take advantage of market mis-valuations. The neoclassical effi- ciency hypothesis suggests corporate actions are initiated for efficiency reasons, and in response to growth and investment opportunities. Event waves may be related to a variety of market timing opportunities (Baker and Wurgler, 2000; Lowry, 2000; Rhodes, Kopf and Viswanathan, 2004). This market driven ap- proach suggests that managers react in a rational way to an irrational market in an attempt to create or take advantage of existing opportunities. Evidence supports this theory (Baker and Wurgler, 2000; Lowry, 2003), but the findings are inconsistent ( Dittmar and Dittmar, 2008). The neoclassical efficiency hypothesis (Gort, 1969) suggests that economic efficiency, not market timing, drives corporate events. This perspective is also well supported, and may provide a better explanation for payout activity (Dittmar and Dittmar, 2008; DeAngelo, DeAngelo and Stulz, 2010). This view suggests that managers undertake corporate transactions for efficiency reasons, and in order to take advantage of growth opportunities. These opportunities may arise in the normal course of the business cycle, or due to industry level shocks. Dittmar and Dittmar (2008) find that repurchases occur in patterns that are driven by business cycle variations, rather than market valuations. 
Capital structure theory and macroeconomic links to the real economy are the final theoretical area on which this work is based. Capital structure may be considered a bridge between corporate finance and the economy, and within this framework, two links are evident. First, capital structure decisions influence payout activity. Second, capital structure decisions are influenced by investment opportunities. Bernanke and Gertler (1989) suggest that investment is the link between the real economy and financial markets. They present a feedback loop in which investment feeds economic activity and economic activity feeds investment. In this model, as the cost of external finance increases, investment decreases, therefore economic activity also decreases. These interactions between the real economy and financial markets happen through three main avenues: the interest rate channel, the wealth effect and the capital structure effect. The focus here is on the interest rate channel and the capital structure effect. Mishkin (1996) presents an overview of interest rate channels and monetary policy transmission that has been a standard in macroeconomic literature. This model suggests that investment is a function of real interest rates. In this model, lower interest rates result in increased investment. This model serves as a basis for intuition regarding macroeconomic interactions,variable selection and hypotheses development. As suggested by Chen, Roll and Ross (1986) the selection of relevant macroeconomic variables requires judgment and a reliance on existing theory and empirical evidence. Theory and evidence guide the variable selections in this research.

I analyze two primary areas as possible explanations for the unexplained variation in aggregate payout activity. I first consider the possibility of a significant industry effect. If present, this has implications on the methods used, as well as provides new insights into payout activity. Industry groups form the basis of the panel methods used in this paper and are a unique contribution to the literature. The industry groups are based on those designed by Fama and French. Floyd, $\mathrm{Li}$ and Skinner (2015) break out industrial and financial industry groups only. I take this idea further and consider seventeen industry groups based on specific definitions outlined by Fama and French and accessed on the website of Eugene Fama on April 24, 2014. The second area I analyze is that of macroeconomic influences. There is an endless list of possible macroeconomic factors. I rely on previous work and begin with the industrial production index (IPI), consumer price index (CPI), money supply (M1), the ten year Treasury rate and the three month Treasury rate. Due to insignificance in all models, I drop some variables and the final models include IPI, the ten year Treasury rate and the three month Treasury rate. Due to the theoretical links previously explained, I control for the market level using an S\&P 500 variable. I also control for the primary firm level determinants of payout activity. I follow the literature and standard econometric practice, and begin with an ordinary least squares (OLS) model followed by a random effect and dynamic panel model.

Following is a brief explanation of the macroeconomic variables included, the motivation for inclusion, and a hypothesis statement. Industrial production (IPI) is a coincident economic indicator. Both theory and empirical evidence suggest that corporate cash flows are related to a measure of aggregate output such as industrial production (IPI). As previously discussed, overall economic activity and investment function within a feedback loop in which overall economic activity drives investment and investment drives overall economic activity (Bernanke and Gertler, 1989). Payout theory suggests that firms decrease payouts during times of increased investment, and increase payouts during periods of declining investment. Following previous research (Chen, Ross and Roll, 1986; Mukherjee and Naka, 1995; Serfling and Miljkovic, 2011) IPI is used as the measure for overall economic activity. There are conflicting views on the expected direction of this relation, both based on the theoretical importance of investment. It has long been assumed that as IPI increases, earnings increase. It is easy to assume that when earnings increase, payouts also increase. However, within the feedback loop mentioned above, an increase in IPI also leads to an increase in investment, which leads to a decline in payouts. An alternative view is that as investment increases, economic output increases and this leads to an increase in payouts. The focus is generally on repurchases, since these are considered the more flexible form of payout. In this unclear environment, this work follows (Dittmar and Dittmar, 2004) and proposes that IPI has a positive relation with aggregate payout activity. This hypothesis is consistent with the neoclassical efficiency hypothesis suggesting firms initiate self-directed events for economic efficiency reasons.

The literature offers a number of different interest rates, as well as a theoretical framework for hypothesis development. To begin with, the spread between long term rates and short term rates is considered a leading economic indicator and short term rates are classified as coincident indicators (Tainer,2006). Short term rates reflect monetary policy changes and long term rates reflect a longer view of the economy; therefore they both provide unique perspectives and contributions. The rates most often used as explanatory factors are the ten year Treasury bond rate and the three month Treasury bill rate. There are two conflicting perspectives in the literature regarding how interest rates may influence payouts. This relates to the issues previously mentioned related to internal investment. In a very simple model, as interest rates increase, the cost of external finance increases, leading to a decline in investment. A decline in investment leads to an increase in payouts, reflecting a positive relation between interest rates and payouts. An alternative that is offered in the literature suggests that as interest rates increase, financing costs increase, leading to a decline in earnings. This drop in earnings leads to a drop in payouts. This reflects a negative relation between interest rates and payouts. I 
include a long term and short term rate to provide a broader perspective on the interest rate influences, and the hypothesis is that there is a negative relation between interest rates and payouts.

This paper is related to Dittmar and Dittmar (2008) which shows that repurchases are the result of economic stimulus, as measured by GDP, and are not primarily driven by market mis-valuation. It also contributes to the literature on trends in repurchase activity (Bagwell and Shoven, 1989; Grullon and Michaely, 2002) and the larger body of literature examining trends in dividends and overall

payout policy (Fama and French, 2001; DeAngelo, DeAngelo and Skinner, 2004; Floyd, Li and Skinner, 2015). This study is organized as follows: Section 2 contains a description of the data. Section 3 includesthe methodology. Section 4 includes results and Section 5 contains a conclusion and discussion.

\section{Data}

This research examines the neoclassical efficiency theory and assumes that rational managers interpret macroeconomic changes and take action based on reasons of overall firm efficiency. The result may be changes in firm fundamentals, and these changes may be happening to many firms at the same time. Each variable is explained within the context of motivation for inclusion. Table 1 contains variable definitions and Table 2 is a list of the industry groups.

Table 1. Data Definitions

\begin{tabular}{|c|c|}
\hline Variable name & Definition ( Compustat code) \\
\hline Assets & Total Assets (AT) \\
\hline Earnings & Income before extraordinary items (IB) \\
\hline Total repurchases & $\begin{array}{l}\text { (P Purchase of common and preferred stock } \\
\text { (PRSTK) minus any reduction in the value of } \\
\text { preferred stock outstanding (PRSTKRV) }\end{array}$ \\
\hline Capital expenditures & CAPX \\
\hline Dividends & Cash dividends (DVC) \\
\hline IPI ( adjusted, base year $2007=100$ ) & $\begin{array}{c}\text { Retrieved from St. Louis Federal Reserve } \\
\text { Bank website }\end{array}$ \\
\hline $\begin{array}{c}\text { S\&P } 500 \\
\text { Ten year Treasury rate }\end{array}$ & $\begin{array}{l}\text { the price level of the S\&P } 500 \text { (Series } \\
\text { SP500) retrieved from the website of Robert } \\
\text { Shiller, Yale University } \\
\text { retrieved from the St. Louis Federal Reserve } \\
\text { Bank website }\end{array}$ \\
\hline Three month Treasury rate & $\begin{array}{l}\text { retrieved from the St. Louis Federal Reserve } \\
\text { Bank website }\end{array}$ \\
\hline Repurchase/total assets & $\begin{array}{l}\text { (PRSTK) minus any reduction in the } \\
\text { value of preferred stock outstanding } \\
\text { (PRSTKRV)/total assets (AT) }\end{array}$ \\
\hline $\begin{array}{l}\text { Dividend / total assets } \\
\text { LogIPI }\end{array}$ & $\begin{array}{l}\text { Total dividends (DVC)/Total assets(AT) } \\
\text { natural logarithm of the industrial } \\
\text { production index (Series INDPRO, } \\
\text { seasonally adjusted),base year } 2007=100, \\
\text { retrieved from St. Louis Federal Reserve } \\
\text { Bank website) } \\
\text { natural logarithm of the price level of the } \\
\text { S\&P500,(Series sp500) retrieved from the } \\
\text { website of Robert Shiller, Yale) }\end{array}$ \\
\hline
\end{tabular}

Because there is also supporting evidence for the market valuation theory, this research follows existing literature (Humpe and Macmillan, 2009; Serfling and Miljkovic, 2011) and controls for the market effect using the log of the level of the S\&P 500 as a proxy for the market effect. This section includes a description of the dependent variables, the seventeen industry groups that serve as the basis for the panel data analysis, and the independent variables. The 
independent variables include both macroeconomic and firm-level variables.

\subsection{Dependent Variables and Industry Groups}

The data sample contains payout variables and firm level variables from Compustat North America annual data, from 1985 to 2011, available through Wharton Research Data Services. Existing literature (Dittmar and Dittmar, 2004; Bliss, Cheng and Denis, 2012) informs variable selection. Cash dividends (DVQ and DVC) are used to calculate total dividends. Share repurchases are the purchase of common and preferred stock (PRSTKC) minus any reduction in the value of preferred stock outstanding (PRSTKRV).

Table 2. Industry Groups

\begin{tabular}{|c|c|}
\hline Industry group number & Industry group name \\
\hline 1 & Food \\
\hline 2 & Auto \\
\hline 3 & Chemicals \\
\hline 4 & Cloth \\
\hline 5 & Consumer Goods \\
\hline 6 & Construction \\
\hline 7 & Consumer Durables \\
\hline 8 & Fabricated Materials \\
\hline 9 & Financial \\
\hline 10 & Machinery and equipment \\
\hline 11 & Mines \\
\hline 12 & Oil \\
\hline 13 & Steel \\
\hline 14 & Transportation \\
\hline 15 & Retail \\
\hline 16 & Utilities \\
\hline 17 & Other \\
\hline
\end{tabular}

As stated previously, the literature provides insight into the use of SIC codes to classify firms by industry group. The SIC system arrays the economy into 11 divisions, that are divided into 83 two-digit major groups, that are further subdivided into 416 three-digit industry groups, and finally disaggregated into 1,005 four-digit industries. Each company will have a primary SIC code. This number indicates the primary line of business. What determines a primary SIC code is the code definition that generates the highest revenue for that company. Payout literature has generally excluded financials with SIC codes 4000-4949 and utilities with SIC codes 6000-6999, and combined all other industries into one group.

It is a contribution to the literature to examine payouts at the industry group level. Due to the large number of industries, a combining process was necessary. It has long been popular to delineate sets of firm specific data by following industry affiliation. Numerous studies provide evidence that industry influences are significant and have numerous applications in finance (Roll, 1986). In the practitioner environment, stock analysis is typically structured based on industry classifications. Deciding how to build groups based on industry classification is far from straightforward, and the Fama and French (1997) method is applied. Fama and French have various different industry groups based on SIC codes. Their industry classification system has been highly utilized in studies that address a variety of corporate finance topics including, but not limited to, asset pricing (Daniel and Titman, 2006: Hong, Torous and Valkanov, 2007) and corporate finance (Flannery and Rangan, 2000.) In order to examine a broad effect using industry groups, the classification of 17 industry groups was selected. This work applies the definitions of their 17 industry portfolios, as defined on the website of Kenneth R. French and accessed on April 24, 2014. 


\subsection{Firm Level Independent Variables}

Existing literature (Dittmar and Dittmar, 2004; Rau and Stouraitis, 2009; Floyd, Li and Skinner, 2011; Bliss, Cheng and Denis, 2012) informs independent variable selection at both the firm level and the macroeconomic level. The firm level variables are: total assets (AT), income before extraordinary items (IB), and capital expenditures (CAPX). The variable non operating income (NOPI) was included but dropped due to the fact that it did not appear significant in any models. Following existing literature (Dittmar and Dittmar, 2004; Bliss, Cheng and Denis, 2012), all firm-level variables are scaled to total assets.

\subsection{Macroeconomic Variables}

Considering macroeconomic variables within the classification system of leading, lagging and coincident pro- vides additional insight into the variable selection. Economic indicators are used to define and identify stages in the business cycle. Leading indicators consistently move or turn before the economy does. Coincident indicators turn in step with the economy and track the progress of the business cycle. Lagging indicators follow the economy and turn after the economy has moved. Lagging indicators play a confirmatory role in the feedback loop. The original factors selected for this research represent all three categories of macroeconomic variables, however as previously mentioned some factors were dropped due to insignificance. Macroeconomic data were retrieved from the St. Louis Federal Reserve Bank website. Data is from 1985 to 2011. Following traditional practice, a natural logarithm was used for all macroeconomic variables, except those already in a percentage format. The factors included are: industrial production index (series INDPRO) with a base year $2007=100$, S \& P 500 stock price index (Series SP500), three month Treasury bill secondary market rate (Series TB3MS ), and the ten Year Treasury rate(DGS10). All quarterly variables with the exception of the three month Treasury rate were seasonally adjusted using following the X11 method. Since all payout variables were annual data, macroeconomic variables were converted by taking the average for each period. Figure 2 and 3 show the trends of aggregate payout variables, IPI, the ten year Treasury rate and the three month Treasury rate.

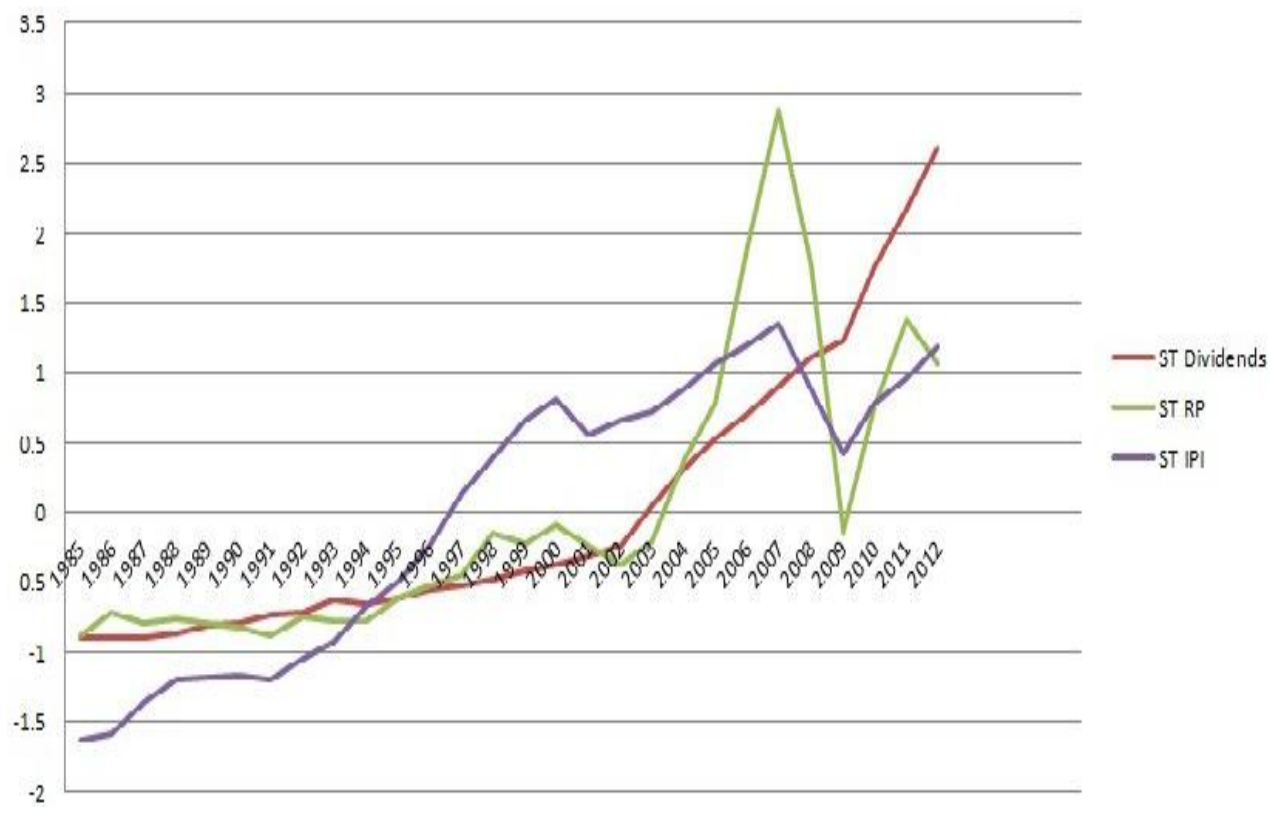

Figure 2. All US firms, 1985-2012: A time series depiction of total dividends, total repurchases, and industrial production index ( Data expressed in 2011 dollars and standardized to common mean and standard deviation) 


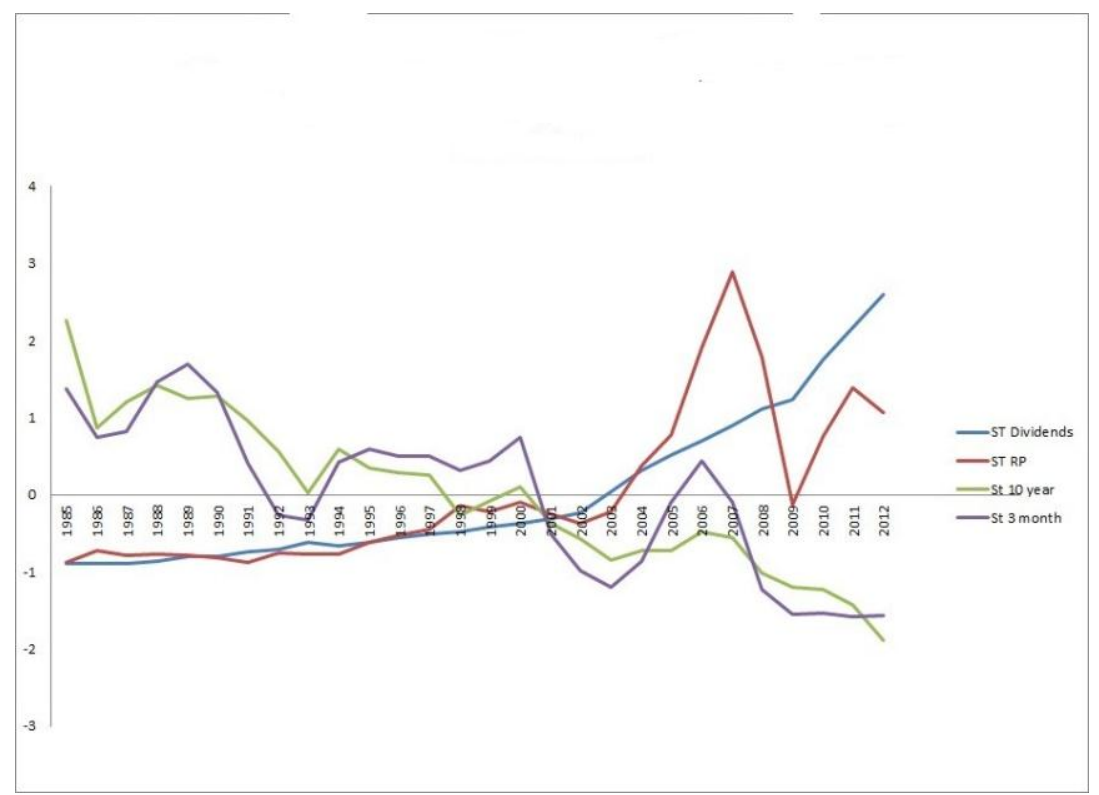

Figure 3. All US firms, 1985-2012: A time series depiction of total dividends, total repurchases, ten year Treasury rate and 3 month Treasury rate (Data expressed in 2011 dollars and standardized to common mean and standard deviation)

Fixed effects are tested by the F test and random effects are tested by the Lagrange Multiplier (LM) test. If the null hypothesis is not rejected in either case, the pooled OLS is favored. If the null is rejected, there is evidence of a fixed or random effect.

The results from both the F Test and the LM test indicate the presence of an industry effect. The Hausman test results on this data indicate that the random effect model is most relevant. Following the application of the random effect model, a dynamic panel model is applied. Based on existing literature and the theoretical importance of lagged dependent variables in payout theory, a dynamic model brings a more complete perspective to this analysis. This research follows Levin et al. (2000) and applies the GMM (Generalized Method of Moments ) model. This model corrects for many of the issues and biases common to finance data such as the presence of unobserved, industry effects, and the endogeneity of explanatory variables and lagged dependent variables (Peterson, 2004).

The following sections review in more detail the random effects model and the Blundell and Bond (1998) GMM model. It is common in existing literature to run a variety of different models and report the results of each. That approach is followed.

\subsection{Random Effects Model}

With a random effects model, the variation in entities is assumed to be random and uncorrelated with the explanatory or independent variables. This is a crucial distinction between the random effects model and the fixed effects model. The random effects model is:

$$
Y i, t=\beta X i, t+\alpha+\mu i, t+E i, t
$$

In this equation, $\mu$ it is the between entity error and Eit is the within entity error. It may be difficult to determine whether fixed effect or random effect is more relevant and significant in panel data. As previously noted, the Hausman test is used to clarify the most appropriate model.

\subsection{Generalized Method of Moments (GMM) Model}

Dynamic panels are becoming more common in corporate finance, however the characteristics of finance data bring serious econometric biases into the analysis. Flannery and Hankins (2013) reviewed these issues in detail. Their work highlights the importance of addressing these issues and they offer methods for addressing them. The methods applied in this paper are based on their work. The underlying issue is the presence of unobserved effects that are expressed in the error term and are correlated with explanatory variables. Using the basic equation

$$
Y i, t=\alpha+\beta x i+E i
$$

In this example, $\beta$ and Ei are correlated. If $\mathrm{x}$ changes, $\mathrm{Y}$ changes in two ways: through $\mathrm{x}$ and through e. The concept in GMM is to find a third variable, $\mathrm{Z}$, that is correlated with $\mathrm{X}$ but not with e. If $\mathrm{Z}$ changes, this causes $\mathrm{x}$ to change and the resulting change to $\mathrm{Y}$ is only from the change in $\mathrm{x}$. There are two primary conditions that must be met. First, the covariance between $\mathrm{Z}$ and the error term is = zero, indicating that changes in $\mathrm{Z}$ do not impact changes in the error term. 
The second condition is that covariance between $\mathrm{z}$ and $\mathrm{x}$ does not equal zero. It is preferred to have a strong positive correlation and a strong relation between $\mathrm{z}$ and $\mathrm{x}$.

The size and format of the panel can impact this bias. In large panels, the bias declines due to an increase in T. With a higher $\mathrm{T}$, the correlation between the lagged dependent variable and the error term decreases, however even when $\mathrm{T}=30$, potentially severe biases remain in finance data (Judson and Owen, 1999). In addition, the data may be not be available. Compustat firms have an average of 15 years of annual data, well short of the number of observations required to make the bias negligible (Flannery and Hankins, 2012). In response to these challenges, econometric techniques have evolved to address these issues. These are based on using instrumental variables techniques involving a third variable, $\mathrm{Z}$, as explained above. If zi changes, this causes Yi to change but only through xi. This eliminates the change to Yi that results from Ei. The techniques focus on computing valid instruments which remove the correlation between variables and the error terms, thus addressing the endogeneity issue. The commmon application in finance literature is to follow work that began with Arellano and Bond (1991) who use a generalized method of moment's framework to develop valid instruments. They first difference the panel data to remove the time invariant effects and show that the lagged dependent variable values constitute legitimate variables. Blundell and Bond (1998) suggest an alternative and use the lagged first differences as instruments in a levels equation. I follow the literature (Levine, Loayza and Beck, 2000; Rachdi and Mbarek, 2011; Flannery and Hankins, 2013) and apply the Blundell and Bond (1998) method.

The basic regression equation is:

$$
Y i, t-Y i,(t-1)=(X-1) i,(t-1)+\beta i, t+n i
$$

where $\mathrm{Y}$ is the $\log$ of real aggregate payout, $\mathrm{X}$ represents a set of explanatory variables other than lagged payout values, $\mathrm{n}$ represents unobserved industry effects and $\mathrm{E}$ is the error term. To eliminate the industry effect, first differences are taken of Equation 10. This method deals with the likely endogeneity of the explanatory variables and the problem with the error terms being correlated with the lagged dependent variable. The GMM estimator based on these conditions is referred to as the difference estimator.

\section{Results}

Results presented include pooled OLS, random effect, and the GMM model. The explanatory factors are in ratio format (scaled to total assets) in order to accommodate the non-stationarity of the aggregate series.This follows the literature (Dittmar and Dittmar, 2004). In order to control for firm-level determinants, earnings and capital expenditures are included. Non-operating income was originally included; however it was insignificant in all models and was dropped from this study. Due to the importance of previous payouts, the lagged value of the dependent variable is included. In order to control for the market value theory of payouts, the log of the level of the S\&P 500 is included. In the GMM model, as previously explained, the lagged value of the dependent variable is used as an instrumental variable. Based on the theoretical framework and intuition outlined previously, the expectation is for a positive relation between dividends and repurchases and IPI, and a negative relation for interest rate variables.

\subsection{OLS Results}

Pooled OLS results are reported in Table 1 and these indicate that there are significant macroeconomic influences, as well as notable differences between the results for dividends and repurchases. Standard errors are reported in parentheses and $* * *, * *$, and $*$ indicate statistical significance at the $1 \%, 5 \%$ and $10 \%$ level respectively.

Results for dividends are not surprising. Firm-level determinants are significant and the coefficients reflect the importance of previous dividends (.7691) and earnings (.8773). Capital expenditures are not significant in this model. This is not surprising since it is assumed that dividends are more consistent and not as closely tied to capital expenditures as repurchases. These findings support that. IPI, the ten year Treasury rate and the three month Treasury rate are all insignificant in this model. This suggests that macroeconomic influences do not enter into the aggregate dividend equation.

Results for repurchases are also not surprising. Firm level determinants are significant and the coefficients, once again, reflect the importance of previous repurchase activity and earnings. The capital expenditures variable is significant and negative in this model. This supports existing theory that suggests that as capital expenditures decline, there are funds available for distribution to shareholders through a repurchase. ea The IPI and the ten year Treasury rate are insignificant,however the three month Treasury rate is significant at the $1 \%$ level and negative. This suggests that as the cost of short term borrowing increases, earnings decrease and payouts decrease. This may indicate a decline in available funds for distribution to shareholders, due to increased interest expenses.

Pooled OLS results are reported in Table 3 and may be problematic if an industry effect exists. The following sections address this issue. 


\subsection{Random Effect Results}

Both a fixed and random effect are applied. A fixed group effect examines differences in intercepts, assuming the same slopes and constant variance across groups. A random effect model assumes that the group effect is not correlated with any regressor and error variance specific to groups. In this case, the difference among groups lies in the errors, not in the intercepts. The Hausman test is used to determine the type of effect and the appropriate model. The Hausman test indicates that the random effect model is most relevant.

Table 3. OLS Results for total dividends and total repurchases

\begin{tabular}{lcc}
\hline Dependent variable & Total Dividends & Total Repurchases \\
\hline Lag(1)dep variable & $.765(.028)^{* * *}$ & $.454(.039)^{* * *}$ \\
Earnings & $.252(.018)^{* * *}$ & $.243(.046)^{* * *}$ \\
CAPX & $-.0127(.0224)^{* *}$ & $-.134(.059)^{* *}$ \\
Logsp & $-.011(.003)$ & $.010(.010)$ \\
LogIPI & $-.002(.012)$ & $.043(.033)$ \\
Tenyear & $-.002(.000)$ & $-.001(.001)$ \\
Threemonth & $.000(.000)$ & $-.002(.000)^{* * *}$ \\
Adjusted R squared & .67 & .37 \\
F Test Probability & .000 & .000 \\
Number of observations & 476 & 476 \\
\hline
\end{tabular}

Random effect results are reported in Table 4 and these indicate that there are significant macroeconomic influences, as well as notable differences between the results for dividends and repurchases. Standard errors are reported in parentheses and $* * *, * *$, and $*$ indicate statistical significance at the $1 \%, 5 \%$ and $10 \%$ level respectively.

Test results indicate the presence of an industry effect, making pooled OLS results biased. This random result identifies the presence of unobserved group effects in the error terms. The percentage of variation due to the industry effect is $16 \%$ for dividends and $11 \%$ for repurchases. This is a significant finding and contribution to the literature. In additional to the methodological implications that were previously introduced, there are practical implications as well. An industry effect suggests that we cannot assume that there is one standard payout equation that can be applied to all industries, and that industry differences should be considered when interpreting results.

Results for dividends are similar to the OLS results. The importance of previous dividend activity and the importance of earnings remain significant at the $1 \%$. Capital expenditures are not statistically significant. IPI and both interest rate variables are insignificant in this model. This finding supports the primary importance of firm level determinants in the dividend equation and the well supported importance of previous dividend decisions.

Results for repurchases vary slightly from the repurchase results using the OLS model. The importance of previous repurchase activity, earnings and capital expenditures is consistent with OLS results. IPI remains insignificant. The change with this model is that the ten year Treasury rate is significant at the $10 \%$ level and reflects a negative relation. The direction of this relation is what is expected and can be explained by the understanding that as the long term cost of borrowing increases, when controlling for capital expenditures, earnings will decrease. This results in a decrease in funds available for distribution to shareholders and a decrease in repurchase activity. The results for the three month Treasury rate vary from the OLS results. The variable remains significant at the 5\% level but the direction is positive. It is not surprising that the results vary with the application of the random effect model, perhaps due to the endogeneity issues. The positive direction may be related to a framework in which short term rates increase and internal investment decreases. This results in excess funds available to distribute to shareholders through the flexible form of a repurchase. The conflicting results on the three month rate may be the result of the endogeneity issues in this model and the GMM model that follows is designed to deal with these issues.

\subsection{GMM Results}

GMM results are reported in Table 5 and these indicate that there are significant macroeconomic influences, and as with the models above, these results indicate notable differences between dividends and repurchases. Standard errors are reported in parentheses and $* * *, * *$, and $*$ indicate statistical significance at the $1 \%, 5 \%$ and $10 \%$ level respectively. In 
response to these challenges in the data and the endogeneity issues, I follow the literature and use a lagged value of the dependent variable as an instrumental variable.

GMM results provide additional clarity, as a result of addressing the endogeneity issues. The results for dividends indicate that all three macroeconomic variables are, at varying levels, significant. IPI is significant at the 5\% level and reflects a positive relation. As previously discussed, there is conflicting evidence regarding the direction of this relation that may be the result of the complexity of a feedback loop process. Economic output and investment function within a feedback loop, so it may be difficult to determine influence. This finding suggests that when controlling for capital expenditure, there is a positive relation between IPI and aggregate dividends, indicating that an increase in economic output exerts a positive influence on aggregate dividend activity.

The ten year Treasury rate is negative and significant at the $10 \%$ level. This suggests that when controlling for firm level factors, an increase in the long term cost of borrowing, leads to a decline in dividends. This is not an unexpected result and it may reflect a number of responses that include a decline in earnings due to the increased cost or borrowing, or it may reflect an response to increased uncertainty regarding the long term outlook. Finally, the 3-month rate is significant at the $5 \%$ level and remains positive.

Table 4. Random effect results for total dividends and total repurchases

\begin{tabular}{lcc}
\hline Dependent variable & Total Dividends & Total Repurchases \\
\hline Lag(1)Dep variable & $.725(.031)^{* * *}$ & $.374(.041)^{* * *}$ \\
Earnings & $.072(.019)^{* * * *}$ & $.240(.052)^{* * *}$ \\
CAPX & $-.008(.025)$ & $-.136(.074)^{* *}$ \\
LogSP & $-.001(.0037)$ & $-.012(.010)^{* *}$ \\
IPI & $.003(.012)$ & $.053(.032)^{* * *}$ \\
Ten Year & $-.001(.003)$ & $-.001(.001)$ \\
Three Month & $.000(.000)$ & $-.002(.001) * *$ \\
Rho & .1684 & .1112 \\
\hline
\end{tabular}

The direction of this result is unexpected, however it provides insight into the difference perspective offered by long term and short term rates. This positive relation between short term rates may reflect a decline in investment that results in an increase in payouts.

Table 5. GMM results for total dividends and total repurchases

\begin{tabular}{lcc}
\hline & Dividend & Repurchase \\
\hline Lag(1) Dep Variable & $.608(.069) * * *$ & $.399(.023) * * *$ \\
Earnings & $.062(.028) * * *$ & $.292(.058) * * *$ \\
CAPX, & $.021(.018)$ & $-.103(.048) * *$ \\
LogSP & $-.001(.001) * * *$ & $-.002(.003)$ \\
IPI & $.004(.002) * *$ & $.009(.005) * *$ \\
Ten Year & $-.003(.000) *$ & $-.002(.000) * * *$ \\
Three month & $.0002(.0001) * *$ & $.0001(.002) * * *$
\end{tabular}


The results for repurchases are similar in that all three macroeconomic variables are significant, and at varying levels also. IPI is positive and significant at the $10 \%$ level. This indicates that as economic output increases, when controlling for capital expenditures, repurchases also increase. The 10-year Treasury rate is negative and significant at the $1 \%$ level. This supports the framework in which repurchases decrease as the cost of external finance increases, perhaps in response to a decline in earnings. Once again, the 3 -month rate is positive and significant at the $1 \%$ level. As previously stated, this may be explained by a response of many firms to cut investment when short term rates increase, allowing funds to be available for both dividends and repurchases.

\section{Discussion and Conclusion}

Establishing an equation for corporate payouts has been an ongoing area of research in corporate finance for decades. Allen and Michaely (2002) suggest that corporate payouts are not so much the result of a set equation, but are the result of a series of corporate decisions that are impacted by determinants that fluctuate over time. These fluctuations, that impact firm-level determinants, result in changes in payout activity and payout policy. In this paper, I examine the dynamic nature of aggregate payout activity by looking beyond firm level, cross-sectional determinants. I focus on examining unexplained variation in aggregate dividend and aggregate repurchase activity by analyzing industry effects and macroeconomic influences.

This research offers significant findings in two areas. The first is that aggregate payout data contains a significant industry effect. This sheds light on methodological implications, as well as offers insights into a more detailed perspective on payout policy. Perhaps there is not one equation for payout policy but a set of determinants and influential factors, and all of these vary by industry. Second, macroeconomic factors do exert significant influence on aggregate payout activity. Returning to the perspective of a payout policy system, as opposed to a payout policy equation, these findings indicate that IPI, the 10-year Treasury rate and the 3-month Treasury rate influence the system. IPI exerts a positive influence indicating that as economic output increases, so do payouts. The 10-year Treasury rate exerts a negative influence, indicating that as rates for external funding increase, earnings are reduced, funds are retained, and payouts decrease. The 3-month rate offers a different perspective on interest rate relations. The 3-month rate exerts a positive influence. A possible explanation for this is that overall, it is short term rates that influence the internal investment decisions of firms. As these rates increase, internal investment is cut and payouts increase.

These findings indicate numerous opportunities for further work. The Fama and French industry clas- sifications are the primary tool for forming industry groups, but there is little evidence of the effectiveness of these groupings (Chan, Lakonishok and Swaminathan, 2007). Examining other ways of building industry groups would be a way to further this study and address current weaknesses. Another opportunity to further this work is to consider other macroeconomic factors and further analyze the short term interest rate re- sult. Including interest rate spread variables may provide additional insight. Finally, there are opportunities to apply this study to other markets. An international perspective would enhance out understanding of corporate payout decisions in other countries, but would also provide insight into the bigger issue of how macroeconomic shocks expose investors to business cycle uncertainty.

\section{References}

Allen, F., \& Michaely, R. (2003). Payout Policy. Handbook of Economics and Finance, edited by G. M. Constantinaides, M. Harris and R. Stultz. Elsevier Science. http://dx.doi.org/10.1016/s1574-0102(03)01011-2.

Arellano, M., \& Bond, S. R. (1991). Some tests of specification for panel data: Monte Carlo evidence and an application to employment equations. Review of Economic Studies, 58, 277-97. http://dx.doi.org/10.2307/2297968.

Bagwell, L. S., \& Shoven, J. B. (1989). Cash distributions to shareholders. Journal of Finance, 81, 71-140.

Baker, M. P., \& Wurgler, J. (2000). The equity share in new issues and aggregate stock returns. Journal of Finance, 55, 2219-2257. http://dx.doi.org/10.1016/j.jfineco.2003.08.001.

Baker, M. P., Stein, J., \& Wurgler, J. (2003). When does the market matter? Stock prices and the investment of equity dependent firms. Quarterly Journal of Economics, 118, 969-1006. http://dx.doi.org/10.3386/w8750.

Bernanke, B., \& Gertler, M. (1989). Agency Costs, Net Worth, and Business Fluctuations. American Economic Review, 79, 14-31.

Bliss, B., Cheng, Y., \& Denis, D. J. (2012). Corporate Payout, Cash Retention, and the Supply of Credit: Evidence from the 2008-09 Credit Crisis, Working Paper, Katz Graduate School of Business, University of Pittsburgh. http://dx.doi.org/10.1016/j.jfineco.2014.10.013.

Blundell, R., \& Bond, S. R. (1998). Initial conditions and moment restrictions in dynamic panel data models. Journal of Economics, 87, 115-43. http://dx.doi.org/10.1016/S0304-4076(98)00009-8. 
Brav, A., Graham, J. R., Harvey, C. R., \& Michaely, R. (2005). Payout policy in the 21st century. Journal of Financial Economics, 77(3), 483-527. http://dx.doi.org/10.1016/j.jfineco.2004.07.004.

Chan, L. K., Lakonishok, J., \& Swaminathan, B. (2007). Industry classifications and return. Financial Analysts Journal, 63(6), 56-70. http://dx.doi.org/10.2469/faj.v63.n6.4927.

Chen, N. F. (1991). Financial investment opportunities and the macro economy, Journal of Finance, 46, 529-554. http://dx.doi.org/10.1111/j.1540-6261.1991.tb02673.x.

Chen, N. F., Roll, R., \& Ross, S. A. (1986). Economic Forces and the Stock Market. Journal of Business, 59, 383-403. http://dx.doi.org/10.2469/faj.v63.n6.4927.

Daniel, K., \& Titman, S. (2006). Market reactions to tangible and intangible information. The Journal of Finance, 61(4), 1605-1643. http://dx.doi.org/10.1111/j.1540-6261.2006.00884.x.

DeAngelo, H., \& DeAngelo, L. (2006). The irrelevance of the MM dividend irrelevance theorem, Journal of Financial Economics, 79, 293-315. http://dx.doi.org/10.1016/j.jfineco.2005.03.003

DeAngelo, H., DeAngelo, L., \& Skinner, D. (2000). Special dividends and the evolution of dividend signaling. Journal of Financial Economics, 57(3), 309-354. http://dx.doi.org/10.1016/S0304-405X(00)00060-X

DeAngelo, H., DeAngelo, L., \& Skinner, D. J. (2003). Are Dividends Disappearing? Dividends Concentration and the Consolidation of Earnings. Journal of Financial Economics, 72(3), 425-456. http://dx.doi.org/10.1016/S0304-405X(00)00060-X.

DeAngelo, H., DeAngelo, L., \& Stulz, R. (2006). Dividend policy and the earned/ contributed capital mix: A test of the lifecycle theory. Journal of Financial Economics, 81(2), 227-254. http://dx.doi.org/10.1016dj.j.fineco.2005.07.005.

DeAngelo, L., \& Skinner, D. (2008). Corporate payout policy. Foundations and Trends in Finance, 3, 95-287. http://dx.doi.org/10.1016/S0304-405X(00)00060-X.

DeAngelo, L., \& Stulz, R. M. (2010). Seasoned equity offerings, market timing, and the corporate lifecycle. Journal of Financial Economics, 95, 275-295. http://dx.doi.org/10.1016/j.jfineco.2009.11.002.

Dittmar A. K., \& Dittmar, R. F. (2008). The timing of nancing decisions: an examination of the correlation financing waves. Journal of Financial Economics, 90, 158.

Dittmar, A. K. (2000). Why do firms repurchase stock? Journal of Business, 73, 331-355. http://dx.doi.org/10.1086/209646.

Dittmar, A. K., \& Dittmar, R. F. (2002). Stock repurchase waves: an explanation of the trends in aggregate corporate payout policy. Working paper.

Dittmar, A. K., \& Dittmar, R. F. (2004). Stock repurchase waves: An explanation of the trends in aggregate corporate payout policy. Working Paper, University of Michigan.

Fama, E. F., \& French, K. R. (2001). Disappearing dividends: changing firm characteristics or lower propensity to pay? Journal of Financial Economics, 60, 3-43. http://dx.doi.org/10.1016/S0304-405X(01)00038-1.

Fama, E. F., et al. (1969). The Adjustment of Stock Prices to New Information. Department of Economics, University of Pennsylvania and Osaka University Institute of So- cial and Economic Research Association, International Economic Review, 10(2), 1-21. http://dx.doi.org/10.2307/2525569.

Flannery, M. J., \& Hankins, K. W. (2013).Estimating dynamic panel models in corporate finance. Journal of Corporate Finance, 19, 1-19. http://dx.doi.org/10.1016/j.jcorpfin.2012.09.004.

Flannery, M. J., \& Rangan, K. P. (2008). What caused the bank capital build-up of the 1990s? Review of Finance, 12(2), 391-429. http://dx.doi.org/10.1016/j0220304-202(01)00011-1.

Floyd, E., Li, N., \& Skinner, D. J. (2015). Payout policy through the financial crisis: the growth of repurchases and the resilience of dividends. Journal of Financial Economics, 118(2), 299-316. http://dx.doi.org/10.1016/j.jfineco.2015.08.002.

Frisch, R., \& Cassel, G. (1933). Propagation problems and impulse problems in dynamic economics.

Gort, M. (1969). An Economic Disturbance Theory of Mergers. Quarterly Journal Econometrica, 46, 1251-71.

Hong, H., Torous, W., \& Valkanov, R. (2007). Do industries lead stock markets, Journal of Financial Economics, 83(2), 367-396. http://dx.doi.org/10.1016/j.jfineco.2005.09.010. 
Humpe, A., \& Macmillan, P. (2009). Can macroeconomic variables explain long-term stock market movements? a comparison of the US and Japan, Applied Financial Economics, 19, 111-119. http://dx.doi.org/10.1080/09603100701748956.

Jensen, M. C. (1986). Agency costs of free cash flow, corporate finance, and takeovers. American Economic Review, 76, 323-9. http://dx.doi.org/10.2139/ssrn.99580.

Levine, R., Loayza, N., \& Beck, T. (2000). Financial Intermediation and Growth: Causality and Causes, Journal of Financial Economics, 46, 31-77. http://dx.doi.org/10.1016/S0304-405X(00)00072-6.

Lintner, J. (1956). Distribution of incomes of corporations among dividends, retained earnings, and taxes. American Economic Review, 46(2), 97-113.

Lowry, M. (2003). Why does IPO volume fluctuate so much?. Journal of Financial economics, 67(1), 3-40. http://dx.doi.org/10.1016/S0304-405X(02)00230-1.

Myers, S. C., \& Majluf, N. S. (1984). Corporate financing decisions when firms have investment information that investors do not. Journal of Financial Economics, 13, 187-220. http://dx.doi.org/10.1016/0304-405X(84)90023-0.

Rachdi, H., \& Mbarek, H. B. (2011). The causality between financial development and economic growth: Panel data co-integration and GMM system approaches, International Journal of Economics and Finance, 3(1).

Rau, P., \& Stouraitis, A. (2009). Patterns in the timing of corporate event waves. Purdue University, West Lafeyette, http://dx.doi.org/10.1017/S0022109010000694.

Rhodes-Kropf, M., \& Viswanathan, S. (2004). Market valuation and merger waves, Journal of Finance, 59, $2685-2718$. http://dx.doi.org/10.1111/j.1540-6261.2004.00713.x.

Roll, R. (1986). The hubris hypothesis of corporate takeovers. Journal of Business, 59, 197-216.

Ross, S. A. (1976). The arbitrage theory of capital asset pricing. Journal of Economic Theory, 13, 341-60.

Serfling, M. A., \& Miljkovic, D. (2011). Time series analysis of the relationships among macroeconomic variables, the dividend yield and the price level of the S500 index. Applied Financial Economics, 21, 1117-1134. http://dx.doi.org/10.1080/09603107.2011.562167.

Skinner, D. (2008). The evolving relation between earnings, dividends, and stock repurchases, Journal of Financial Economics, 87, 582609. http://dx.doi.org/10.1016/j.jfineco.2007.05.003.

Yule, G. (1927). On a Method of Investigating Periodicities in Disturbed Series, with Special Reference to Wolfer's Sunspot Numbers. Philosophical Transactions of the Royal Society of London. Series A, Containing Papers of a Mathematical or Physical Character, 226, 267-298.

\section{(cc) $\mathrm{BY}$}

This work is licensed under a Creative Commons Attribution 3.0 License. 